\title{
階段式魚道のプール形状変化が魚の休䕀場所 および遡上特性に及ぼす影響
}

\author{
鬼束 幸樹 ${ }^{*}$ ・秋山 壽一郎 ${ }^{2} \cdot$ 松田 孝一郎 ${ }^{3} \cdot$ 藏本 更織 ${ }^{4} \cdot$ 野口 翔平 $^{4}$ \\ ${ }^{1}$ 九州工業大学大学院准教授 工学研究院建設社会工学研究系（†804-8550 北九州市戸畑区仙水町1-1) \\ 2九州工業大学大学院教授 工学研究院建設社会工学研究系（† 804-8550 北九州市戸畑区仙水町1-1） \\ 3 東洋建設株式会社大阪本店（干541-0043 大阪市中央区高麗橋4丁目1-1） \\ 4九州工業大学大学院 工学府建設社会工学専攻（†804-8550 北九州市戸畑区仙水町1-1） \\ * E-mail: onitsuka@civil.kyutech.ac.jp
}

河川にダムや堰などが設置されると，一般的に魚道が併設される．高い遡上率を確保するには，魚道の 適切な幾何学形状の把握が必要である. 日本で採用例が最多の魚道は階段式魚道である. 高い遡上率を確 保するためには，プール幅よりプール長が大きい方がよい，ところが，階段式魚道のプール形状に関して， プールの平面形状が矩形の場合についてのみ検討しており，その他のプール形状に関しては議論がされて いない，本研究では，階段式魚道におけるプールの平面形状と流量を変化させ，オイカワの遡上特性に及 ぼす影響を解明した，その結果，プールの平面形状を変化させることで魚の休憩場所と遡上経路をある程 度限定できることが解明され，魚の遡上に適したプールの平面形状を提案した。

Key Words : pool and weir fishway, Zacco platypus, migration rate, form of pool

\section{1. はじめに}

ダムや堰等の河川横断構造物によって生じる水位落差 は，魚の遡上および降下を妨げる．乙のため，水位落差 を分割あるいは滑らかに接続し，魚類の遡上および降下 を可能にする魚道が設置される場合がある ${ }^{1-9}$. 我が国の 既設魚道の9割以上は階段式魚道である. 高い遡上率を 確保するためには，魚道の適切な幾何学形状の把握が必 要である. 鈶直断面のプール形状変化，つまりプール水 深の変化が魚の遡上特性に及ぼす影響についての研究は 多く行われてきた ${ }^{10-11)}$. しかしながら，水平断面のプー ル形状変化についての研究は，過去の事例が少ない．国 土交通省河川局が発表した「魚がのぼりやすい川づくり の手引き」 ${ }^{12)}$ では，魚道の水平断面において，高い遡上 率を確保するためには，プール幅よりもプール長が大き い方がよいと推奨している.

以上のように，階段式魚道のプール形状に関する研究 は幾分進められているが，これらの報告はプールの平面 形状が矩形の場合についてのみ検討しており，その他の 形状については議論されていない. そのため，平面形状
が矩形の場合が最も適切なプール形状とは言い切れない. よって, プールの平面形状が矩形以外の場合における魚 の遡上特性の解明も必要である.

本研究では，階段式魚道におけるプールの水平断面形 状および流量を系統的に変化させ，才イカワの遡上実験 を行い，遡上特性に及ぼす影響を解明した。

\section{2. 実験装置および実験条件}

図-1 に示すプール長 $L_{x}=0.9 \mathrm{~m}$, プール幅 $B=0.8 \mathrm{~m}$, 隔 壁厚 $\Delta x=0.2 \mathrm{~m}$, 落差および切欠き深さ $\Delta y=0.15 \mathrm{~m}$, 切欠 き幅 $\Delta z=0.15 \mathrm{~m}$ の木製の階段式魚道を実験に用いた。な お，階段式魚道の各諸量は，実河川における実測值およ び国土交通省河川局の推奨值に準じて設定した ${ }^{12-13)}$. 流 下方向に $x$ 軸， $x$ 軸に直角上向きに $y$ 軸, プール横断 方向に $z$ 軸を取り, $x / L_{x}=0,1.0$ の位置において, $z / B=0 \sim 0.2$ の範囲に切欠きを設置した. また，プー ル水深を $h$ とした. ここで，プールの名称は下流から上 流に向かって第 1 , 第 2 , 第 3 プールとする. 第 2 プー 


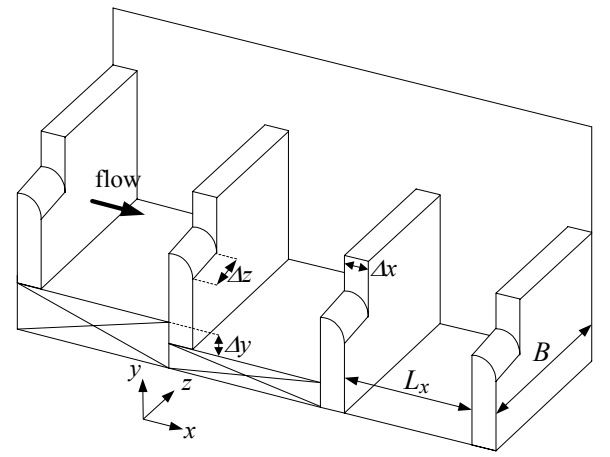

図-1＼cjkstart実験に用いた魚道の概略図

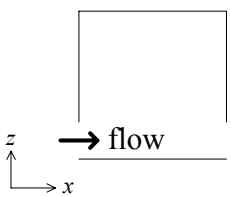

(a) normal

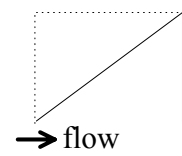

(b) spread

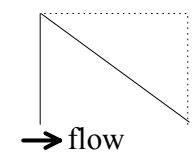

(c) narrow
図-2 第 2 プールの水平断面図

表-1 実験条件

\begin{tabular}{|c|c|c|c|}
\hline$\widehat{Q(1 / \mathrm{s})}$ form & normal & spread & narrow \\
\hline 1 & noQ1 & spQ1 & $\mathrm{naQ1}$ \\
\hline 5 & noQ5 & spQ5 & naQ5 \\
\hline 9 & noQ9 & spQ9 & naQ9 \\
\hline 13 & noQ13 & spQ13 & naQ13 \\
\hline
\end{tabular}

ルの平面形状を矩形形状，上流側切欠きから下流側切欠 きに向かってプール幅が徐々に広くなる形状，狭くなる 形状の 3 種類に変化させ, 更に流量 $Q$ を 1 13(1/s)の範 囲で 4 通りに変化させた合計 12 ケースの実験を行なっ た. なお，第 3 プールから第 2 プールへ水が越流する際 の越流水脈の乱れは観察されなかった. 図-2(a)〜 (c)に 第 2 プールの形状変化を示す. 以下では図-2(a)〜 (c)の プール形状名をそれぞれ normal, spread, narrow と呼称す る. 表-1 に実験条件を示す。実験ケース名は，プール 形状名の最初の 2 文字と流量 $Q$ を表し, 例えば noQ5 は プール形状が normal で, 流量 $Q=5(1 / \mathrm{s})$ を意味する.

実験には平均体長 $\bar{B}_{L}$ が $80 \mathrm{~mm}$ のオイカワを 50 尾用い た. なお，遊泳型および体長が同一であれば，魚種が異

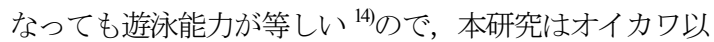
外の魚種にも適応できると考えられる. 第 2プールに才 イカワ 50 尾を放流して流水を開始した. 目視で定常を 確認した後, 切欠きに設置した遡上防止ネットを除去す ると共に，プールの左岸側壁および上部に設置した $1080 \times 810$ の画素数を有する 2 台のカメラで $30 \mathrm{fps}, 30$ 分 間の撮影を行った.
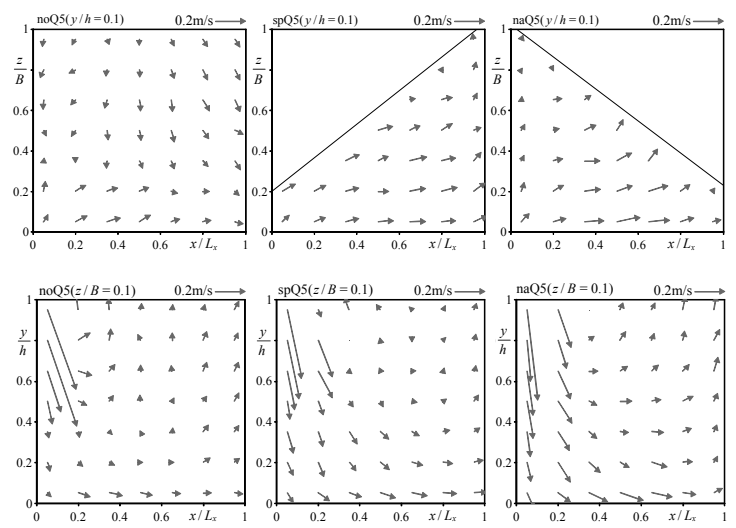
(a) normal
(b) spread
(c) narrow

図-3 流速ベクトル図
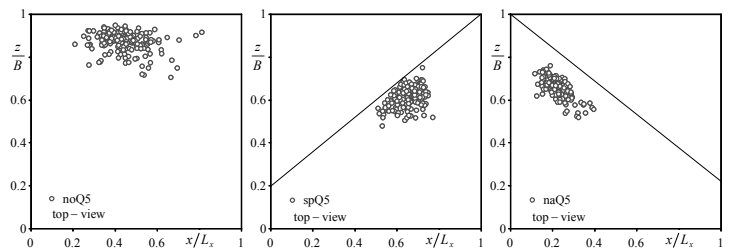

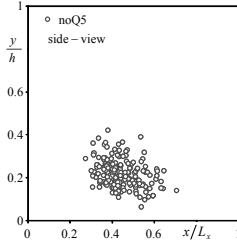

(a) normal

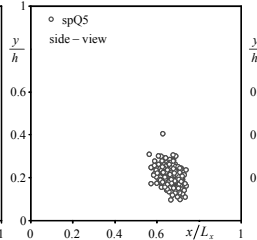

(b) spread

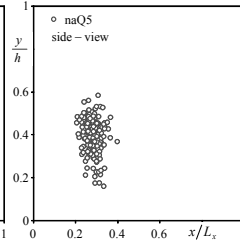

(c) narrow
図-4 瞬間魚群重心の移動状況
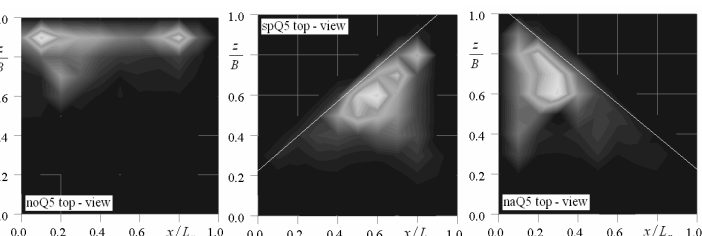

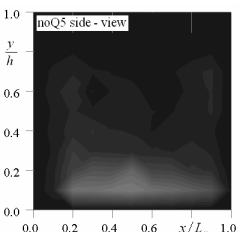

(a) normal

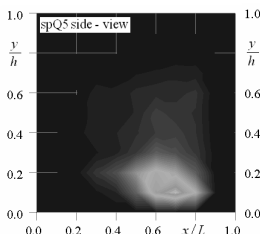

(b) spread

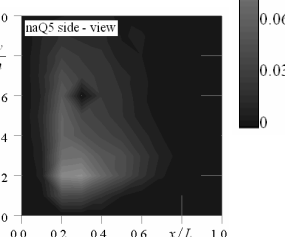

(c) narrow
図-5 魚の存在率コンター

$x, y, z$ 軸方向にそれぞれ 7，9，7 点のメッシュで 構成される合計 441 点において，3 次元電磁流速計を用 いて流速 3 成分を $0.05 \mathrm{~s}$ 間隔で $25.6 \mathrm{~s}$ 計測した。 なお，流 


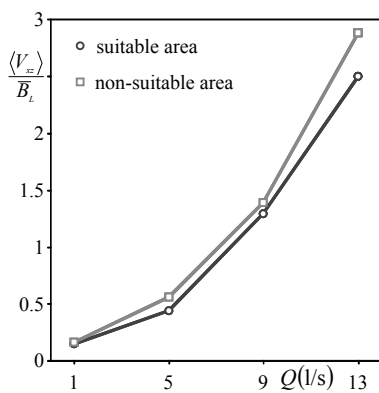

(a) normal

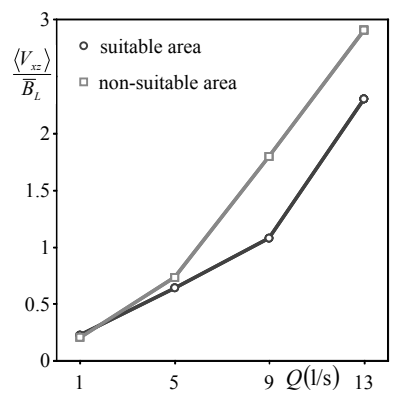

(b) spread

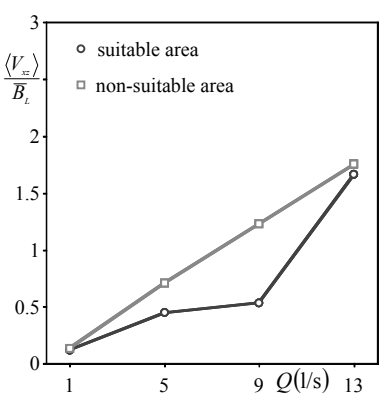

(c) narrow

図-6 魚の休憩・非休憩場所の空間時間平均流速

速測定時には魚道にオイカワを放流していない.

\section{3. 実験結果および考察}

\section{（1）プール内の水理特性}

図-3(a) 〜 (c) に一例として, 流量 $Q=5(\mathrm{l} / \mathrm{s})$ の場合の $z / B=0.1$ における鉛直断面内 $(x-y)$ の流速ベクトルお よび $y / h=0.1$ における水平断面内 $(x-z)$ の流速べクト ルをプール形状別に示寸. 鉛直断面に着目すると, 全て のプール形状において, 落下流の流入部付近に同断面の 他の領域よりも高速な流れが存在している事が理解でき る. それ以外の領域では流速が遅くなっている. 一方, 水平断面に着目寸ると, 全てのプール形状において, 上 流側切久きから下流側切久きに向かって同断面の他の領 域よりも高速な流れが観察される。それ以外の領域を観 察すると, 全てのプール形状において低流速だが, spreadでは，設置した隔壁に沿うように高速流が流れ込 んでいる.

\section{（2）魚の休賃場所の定義}

図-4(a) (c) に一例として, 流量 $Q=5(1 / \mathrm{s})$ の場合の鉛 直断面内 $(x-y)$ および水平断面内 $(x-z)$ における 10 秒 ごとの魚群の重心位置をプール形状別に示す．鉛直断面 に着目すると，ほとんどのケースにおいて魚群重心は半 水深以下に位置していることがわかる. また, 魚群重心 の時間変化は小さい. 一方, 水平断面に着目寸ると, 全 てのプール形状で切欠きから離れた場所に定位している ことが窺える. また, 魚群重心の時間変化は小さい、し たがって, 各プール形状において, 魚は特定の領域を選 好すると判断される.

プールの鉛直断面 $(x-y)$ および水平断面 $(x-z)$ を各 10 分割して得られる 100 メッシュ内の尾数を 10 秒ごと にカウントし, 時間平均尾数 $n^{\prime}$ を算出した. 図-5(a) (c) に流量 $Q=5(1 / \mathrm{s})$ の場合の鉛直断面内 $(x-y)$ および水
平断面内 $(x-z)$ における魚の存在率 $n^{\prime} / N$ のコンターを プール形状別に示寸. ここで, $n^{\prime} / N$ が 0.03 以上の領域 を魚の休憩場所(suitable area), その他の領域を非休喤場所 (non-suitable area) と定義する. 鉛直断面に着目すると，全 てのプール形状において魚の休憩場所は底面付近である。 一方，水平断面に着目寸ると，魚群重心と同様に，全て のプール形状で切欠きから離れた場所で休憩しているこ とが窥える.

図-6(a)〜 (c) に休喤場所および非休憩場所の空間時間 平均流速 $\left\langle V_{x z}\right\rangle$ を平均体長 $\bar{B}_{L}$ で除した值をプール形状別 に示寸．魚の休憩場所は他の領域よりも低流速である.

したがってオイカワは他の領域よりも低流速な領域で休 憩する傾向があることが理解される.

\section{（3）休毠場所と遡上経路との関係}

図-7(a) (c) に一例として, 流量 $Q=5(1 / \mathrm{s})$ の場合の鉛 直断面内 $(x-y)$ および水平断面内 $(x-z)$ の魚の代表的な 遡上経路をプール形状別に示す. 全てのプール形状で代 表的な遡上経路が 2 通り確認できた. それぞれの経路を 観察すると，上流側切欠きから下流側切欠きに向かう高 速な流れ (以後, 高流速域と呼称する) 一の進入の仕方に 違いがあることが理解できる．実線で示している経路は 上流側切欠きから遠い位置より高流速域に進入しており， 点線で示している経路は上流側切久きから近い位置より 高流速域に進入している. したがって, 遡上経路におけ る高流速域の割合によって遡上経路を 2 種類に大別する ことができた．高流速域内の滞在時間は，明らかに点線 で示している経路よりも実線で示している経路の方が大 きい，そのため，流速を考慮した遡上距離が大きい事が 示唆される. そこで, 実線を rapid-flow route, 点線を slowflow route と呼称し, 更に各遡上経路を選択した魚の尾数 を $N_{1}$ および $N_{2}$ とする.

図-8(a)〜 (c) に各遡上経路を選択した魚の尾数 $N_{1}$ お よび $N_{2}$ を，実験に用いた魚の総尾数 $N$ で除した遡上経 路の選択率をプール形状別に示寸. normal では rapid-flow 
route の選択率が高いが， spread，narrow では slow-flow route の選択率が高くなっており，特に spread の場合に slowflow route $の$ 選択率が高い.

図-9(a)〜 (c) に一例として, $Q=1(1 / \mathrm{s}), Q=5(1 / \mathrm{s})$ の 場合の水平断面内 $(x-z)$ における流速べクトルと魚向を プール形状別に示す. $Q=1(1 / \mathrm{s})$ の場合, 全てのプール 形状において魚はランダムな方向を向いていることが理 解できる．これは，流速が低いため，ほとんどの魚が上 流を認知できなかった事が原因と考えられる.

次に $Q=5(1 / \mathrm{s})$ の場合に着目する. nomal では左岸側 壁を向いて魚が定位している．流速べクトルを見てもわ かるように，左岸側壁にぶつかって跳ね返ってきた流れ に対する正の向流性が働いているからと考えられる. spread では, 設置した隔壁付近で上流側を向いて魚が定 位している．これは設置した隔壁に沿って流れが形成さ れているからと考えられる. narrow では，上流側を向い たり，上流側隔壁を向いたり，魚向はランダムである.

これは，上流側隔壁と設置した隔壁の間で流れがぶつか り合い, 複雑な流況になっているからと考えられる. な お, $Q=9(1 / \mathrm{s})$ および $Q=13(1 / \mathrm{s})$ においても， $Q=5(1 / \mathrm{s})$ の場合と同様の傾向を示していた.

各プール形状での魚向を考慮すると, spread では図5 (b)に示している休憩場所で上流側切欠き方向を向いて 定位しているため, 設置した隔壁に沿って遡上する slow-flow route の選択率が高くなったと考えられる.

オイカワには正の向流性があり, rapid-flow routeのよう に高速流に逆らって遡上寸る傾向があるが，プール形状 を変化させ魚の休憩場所を限定することにより，魚の遡 上経路を限定できることが明らかとなった.

\section{（4）休熄場所と遡上経路との関係}

図-10(a)〜 (c) に各遡上経路において遡上に成功した 魚の尾数 $n_{1}$ および $n_{2}$ を, 各遡上経路を選択した魚の尾 数 $N_{1}$ および $N_{2}$ で除した遡上成功率をプール形状別に示 す、ほとんどのケースで， slow-flow route の遡上成功率が 高いことが理解できる. 次に, 各遡上経路間で遡上成功 率に差違が生じた原因を考える. 図-9 の流速ベクトルに 着目すると, 高流速域における流速は大凡 $0.4 \mathrm{~m} / \mathrm{s}$ を超え ており, 体長倍流速では 5 倍以上であることが理解でき る. 魚は体長倍流速が 4 倍より大きい場合, 普通筋を使 用するため, 疲労が蓄積しや寸い ${ }^{15}$. よって, 高流速域 内の滞在時間が長い rapid-flow routeでは, 遡上成功率が低 くなったと考えられる. 一方, slow-flow route の場合, 高 流速域内の滞在時間が短い上, 遡上距離も短いため, 遡 上成功率が高くなったと考えられる。したがって，上流 側切欠きより近い位置から高流速域に進入して遡上を試 みると, 遡上成功率が高くなることが明らかとなった.

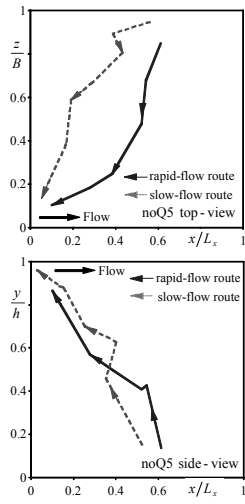

(a) normal

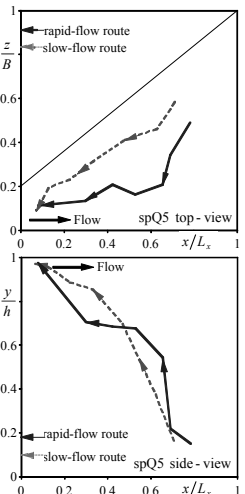

(b) spread
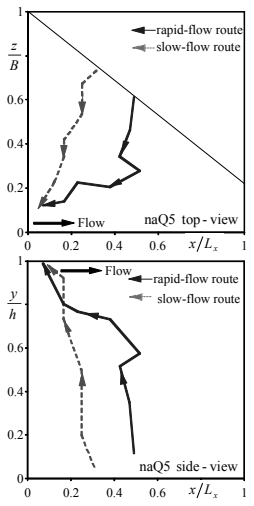

(c) narrow

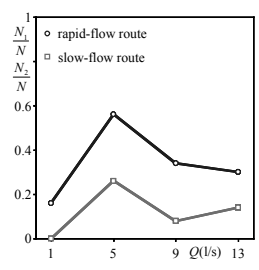

(a) normal

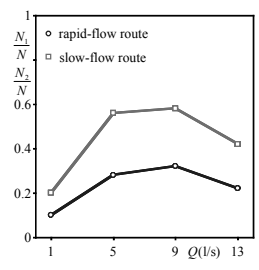

(b) spread

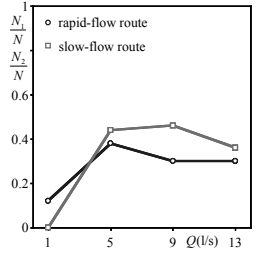

(c) narrow

図-8 遡上経路の選択率
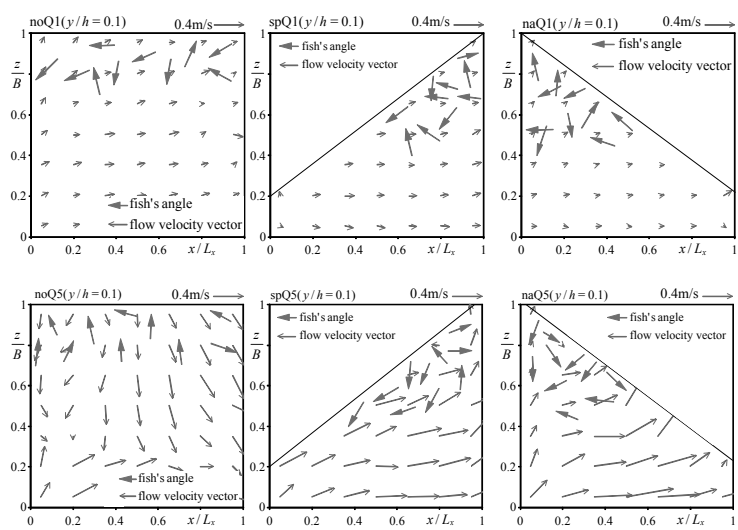

(b) spread

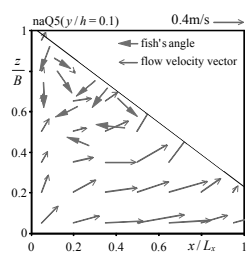

(a) normal

図-9＼cjkstart流速ベクトルと魚向

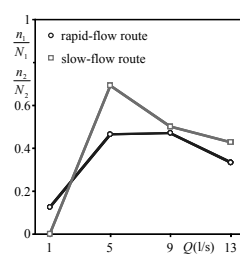

(a) normal

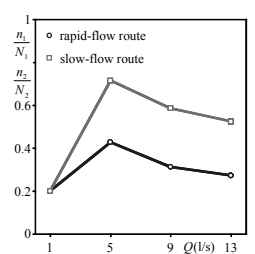

(b) spread

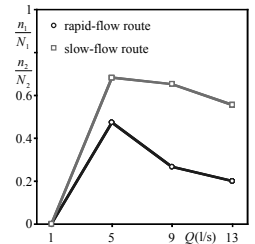

(c) narrow

図-10 遡上成功率 


\section{4. おわりに}

本研究は，階段式魚道のプールの形状を変化させ，才 イカワの遡上実験を行い，プールの形状変化が魚の休憩 場所および遡上特性に及ぼす影響を解明したものである。 その結果，以下の知見が得られた。

（1）プールの形状を変化させると，魚の休櫋場所を限 定することができ，更に魚の遡上経路を限定できること が判明した.

（2）魚の遡上経路には上流側切欠きから遠い位置より 高流速域に進入して遡上寸る経路と，上流側切欠きから 近い位置より進入して遡上する経路の 2 通りがあり，後 者は魚に疲労が蓄積せず，遡上成功率が高くなることが 判明した.

（3）上流側切欠きから下流側切欠きに向かってプール 幅が徐々に広くなるプール形状にすると，上流側切欠き から魚の定位場所に向かって流れが形成されるため，隔 壁に沿って遡上しや寸くなり，必然的に遡上成功率が高 くなる遡上経路を魚が選択しやすくなることが判明した。

謝辞 : 本研究を実施するに当たり, 科学研究費補助金基 盤研究(C) 23560610 (代表 : 鬼束幸樹) の援助を受けた.

\section{参考文献}

1) 高嶋信博，中村俊六 : 魚道内のアユの挙動に関する実験的 研究，第 28 回水理講演会論文集，pp.353-358，1984.

2) 中村俊六 : 魚道の設計，水工学に関する夏季講習会，A-6-124, 1991.

3) 篠邊三郎 : 魚道の設置数, 形式, 勾配について, 農業土木 学会誌，第 57 巻，第 12 号，pp.1183-1187，1989.

4）高崎忠勝，土屋十图，大竹義男 : 秋川における複合型魚道 の効果，河川技術に関する論文集，第 5 巻，pp.165-170,
1999.

5) 和田吉弘 : 魚道の設計で知っておきたいこと, 応用生態工 学, Vol.3, No.2, pp.225-230, 2000.

6) 石川雅朗, 白井淳治, 胡夫祥, 東海正 : バーチカルスロッ 卜型実験魚道におけるウグイ魚群の遡上経路と行動，水産 工学, Vol.43, No.1, pp.9-20, 2006.

7) 安田陽一 : 魚道整備における工学と生態学との連携, 日本 水産学会誌，第 73 巻，第 1 号，pp.116-119， 2007.

8) 浪平篤，後藤眞宏，小林宏康 : 勾配 $1 / 5$ の階段式魚道にお ける流況とウグイの遊泳行動，水工学論文集，第 52 巻, pp.1189-1194, 2008.

9) 鬼束幸樹，秋山壽一郎，松田孝一郎，寺島大輔 : 潜孔の設 置位置がアユの遡上特性に与える影響, 水工学論文集, 第 55 巻, pp.1429-1434, 2011.

10）林田寿文, 本田隆秀, 亘場祐一, 島谷幸宏 : 階段式魚道の プール内流況とウグイの遊泳行動，水工学論文集，第 44 巻, pp.1191-1196, 2000.

11) 真山紘：サケ親魚のそ上行動実験, 魚と卵，第 157 号, pp.4455, 1988.

12）国土交通省河川局 : 魚がのぼりやすい川づくりの手引き, pp.57-58, 2005.

13）鬼束幸樹, 秋山壽一郎, 川良典彰, 飯國洋平，木内大介 : 階段式魚道におけるプランジングフローとストリーミング フローの発生予測式の提案，環境工学研究論文集，Vol.44， pp.49-58, 2007.

14) Katopodis, C., Proc. Of the Int. Symp. On Fishways '90 in Gifu, pp19-28, 1990.

15) 海洋生物環境研究所 : 新しい遊泳能力測定装置による海産 魚類の遊泳能力の評価, 1991.

(2012. 5. 25 受付)

\section{EFFECTS OF HORIZONTAL FORM OF POOL-AND-WEIR FOSHWAY ON MIGRATION CHARACTERISTICS OF FISH}

\section{Kouki ONITSUKA ${ }^{1}$, Juichiro AKIYAMA ${ }^{1}$, Koichiro MATSUDA ${ }^{2}$, Saori KURAMOTO ${ }^{1}$, and Shohei NOGUCHI ${ }^{1}$}

${ }^{1}$ Civil Engineering, Kyushu Institute of Technology

${ }^{2}$ Toyo construction

Fishways have been constructed to facilitate migration of fish past dams, waterfalls and rapids. It is necessary to understand appropriate geometrical shape of the fishway. The most of fishway in Japan is pool-and-weir fishway. In order to get high value of migration rate, it is necessary to set up pool length is larger than width of pool. However there is little information of effects of the form of the pool on migration rate from other than a rectangle. In this study, the form of the pool in a pool-and-weir fishway was changed 3 patterns and the discharge in each form was changed. It was found that the form of pool affects on the migration route. 